\title{
PENGARUH FAKTOR-FAKTOR PERUSAHAAN, PREDIKSI KEBANGKRUTAN DAN REPUTASI AUDITOR TERHADAP PENERIMAAN OPINI AUDIT TERKAIT GOING CONCERN
}

\author{
Augustpaosa Nariman \\ Fakultas Ekonomi Jurusan Akuntansi, Universitas Tarumanagara Jakarta \\ Email: augustpaosa@yahoo.com
}

\begin{abstract}
ABSTRAK
Penelitian ini bertujuan untuk menguji dan menganalisis Pengaruh Faktor-Faktor Perusahaan, Prediksi Kebangkrutan Dan Reputasi Auditor Terhadap Penerimaan Opini Terkait Going Concern (Studi Empiris Pada Perusahaan Pertambangan Batu Bara Yang Terdaftar Di BEI Tahun 2012-2015). Faktor-faktor perusahaan meliputi pertumbuhan perusahaan, kepemilikan institusional, ukuran perusahaan, prediksi kebangkrutan yang dihitung dengan menggunakan Altman Z Score, dan reputasi auditor yang dibedakan menjadi KAP big four dan KAP non big four. Data yang digunakan dalam penelitian ini adalah laporan keuangan perusahaan pertambangan batu bara yang telah diaudit oleh kantor akuntan publik yang terdaftar di Bursa Efek Indonesia periode 2012-2015. Variabel independen dalam penelitian ini adalah pertumbuhan perusahaan dengan melihat pada pertumbuhan aktiva akhir tahun dibandingkan dengan aktiva awal tahun $\left(X_{1}\right)$, kepemilikan perusahaan dengan melihat pada besarnya jumlah saham yang dimiliki oleh institusi $\left(X_{2}\right)$, ukuran perusahaan dengan menghitung Log dari total aktiva akhir tahun $\left(X_{3}\right)$, prediksi kebangkrutan Altman Z-Score dengan menggunakan lima variabel yang mewakili rasio likuiditas, profitabilitas, rasio aktivitas $\left(X_{4}\right)$, dan reputasi auditor yang dibagi menjadi KAP big four dan KAP non big four $\left(X_{5}\right)$ dan variabel dependen dalam penelitian ini adalah opini audit going concern yang diterbitkan oleh kantor akuntan publik. Hasil penelitian menunjukkan hasil bahwa pertumbuhan perusahaan, kepemilikan institusional, ukuran perusahaan, reputasi auditor tidak memiliki pengaruh signifikan terhadap penerimaan opini audit going concern, sedangkan prediksi kebangkrutan dengan menggunakan model Altman Z Score menunjukkan hasil pengaruh yang signifikan terhadap penerimaan opini audit going concern. Auditor akan melakukan analisis terhadap rasio keuangan perusahaan yang menunjukkan kinerja keuangan perusahaan yang akan mempengaruhi opini audit yang akan diberikan oleh kantor akuntan publik.
\end{abstract}

Kata kunci: Pertumbuhan Perusahaan, Kepemilikan Institusional, Ukuran Perusahaan, Altman Z Score, Reputasi Audit

\section{PENDAHULUAN}

\section{Latar Belakang}

Informasi kinerja keuangan yang diterbitkan oleh Perusahaan terdiri dari Laporan Posisi Keuangan Perusahaan dan Laporan Laba/Rugi Perusahaan yang telah diaudit oleh Kantor Akuntan Publik, di mana dalam laporan keuangan tersebut dapat memberikan gambaran kinerja keuangan Perusahaan yang sangat dibutuhkan oleh para pemangku kepentingan dan para investor. Hasil kinerja keuangan Perusahaan yang ditunjukkan dengan Laporan Rugi Perusahaan dan rasio keuangan yang tidak baik dapat mengindikasikan bahwa Perusahaan tersebut sedang mengalami kesulitas keuangan (financial distress). Kesulitan keuangan (financial distress) dapat ditandai dengan ketidak mampuan Perusahaan dalam memenuhi semua kewajiban hutangnya dan ketidak mampuan dalam menghasilkan arus kas yang baik dalam menjalankan bisnis operasi Perusahaan.

Pada saat terjadi krisis keuangan global pada tahun 2008 ketika harga-harga komoditas menurun begitu cepat. Indonesia terkena pengaruh faktor-faktor eksternal ini karena ekspor komoditas (terutama untuk batubara dan minyak sawit) berkontribusi untuk sekitar 50\% dari total ekspor Indonesia, sehingga membatasi pertumbuhan PDB tahun 2009 sampai 4,6\% (yang boleh dikatakan masih cukup baik, terutama didukung oleh konsumsi domestik). Pada tahun 20102013 terjadi kelebihan suplai yang sangat besar dan diperburuk oleh antusiasme para penambang batubara untuk memproduksi dan menjual batubara sebanyak mungkin karena rendahnya harga batubara global dalam rangka menghasilkan pendapatan dan keuntungan. Selain itu juga 
menurunnya tren pendapatan perusahaan pertambangan batu bara juga akan berpengaruh terhadap harga saham perusahaan pertambangan batu bara di bursa.

Hasil penelitian Januarti (2009) yang melakukan penelitian terhadap perusahaan manufaktur menyatakan bahwa default, size, audit client tenure, prior opinion, dan kualitas auditor mempengaruhi pemberian opini audit going concern, sedangkan variabel financial distress, kepemilikan manajerial, kepemilikan institusional, audit lag tidak mempengaruhi pemberian opini audit going concern. Kurniati (2012) yang melakukan penelitian terhadap variabel prediksi kebangkrutan, pertumbuhan dan reputasi KAP terhadap opini audit going concern menyatakan bahwa variabel prediksi kebangkrutan yang berpengaruh signifikan terhadap penerimaan opini audit going concern sedangkan variabel pertumbuhan perusahaan dan reputasi auditor tidak berpengaruh signifikan terhadap penerimaan opini audit going concern. Halimah (2011) menyatakan bahwa debt default berpengaruh terhadap penerimaan opini audit going concern, sedangkan kualitas audit dan pertumbuhan perusahaan tidak berpengaruh terhadap penerimaan opini audit going concern. Setyarno dan Januarti (2006) menyatakan bahwa variabel kondisi keuangan perusahaan dan opini audit tahun sebelumnya berpengaruh signifikan terhadap penerimaan opini audit going concern, sedangkan kualitas audit dan pertumbuhan perusahaan tidak menunjukkan pengaruh yang signifikan terhadap penerimaan opini audit going concern.

Opini audit going concern juga akan dipengaruhi oleh informasi non finansial seperti kepemilikan institusional, di mana semakin besar kepemilikan institusional dan manajerial, maka akan semakin efisien pemanfaatan keuangan perusahaan. Dengan demikian perusahaan akan terhindar dari potensi terjadinya kesulitan keuangan dalam perusahaan. Going concern adalah merupakan satuan usaha dalam mempertahankan kelangsungan hidupnya selama periode waktu yang pantas, yaitu tidak lebih dari satu tahun sejak tanggal laporan keuangan auditan (SPAP, $2011 ; 341.2)$.

Dalam hal ini peneliti termotivasi untuk mengetahui dan menganalisis lebih lanjut bagaimana pengaruh faktor-faktor perusahaan yang meliputi pertumbuhan perusahaan, kepemilikan institusional, ukuran perusahaan, reputasi auditor dan kondisi keuangan perusahaan pertambangan batu bara yang dapat mengindikasikan adanya kebangkrutan terhadap penerimaan opini terkait going concern pada perusahaan sektor pertambangan batu bara. Pengujian dilakukan terhadap Perusahaan pertambangan batu bara yang terdapat di BEI tahun 2012-2015 yang telah diaudit oleh Kantor Akuntan Publik.

\section{Rumusan Masalah}

Perumusan masalah dalam penelitian ini sehubungan dengan latar belakang permasalahan di atas dirumuskan sebagai berikut: 1. Apakah Pertumbuhan Perusahaan memiliki pengaruh positif secara signifikan terhadap penerimaan opini terkait going concern pada perusahaan pertambangan batu bara yang terdaftar di BEI tahun 2012-2015? 2. Apakah Kepemilikan Institusional memiliki pengaruh positif secara signifikan terhadap penerimaan opini terkait going concern pada perusahaan pertambangan batu bara yang terdaftar di BEI tahun 2012-2015? 3 . Apakah Ukuran Perusahaan memiliki pengaruh positif secara signifikan terhadap penerimaan opini terkait going concern pada perusahaan pertambangan batu bara yang terdaftar di BEI tahun 2012-2015? 4. Apakah Prediksi Kebangkrutan memiliki pengaruh positif secara signifikan terhadap penerimaan opini terkait going concern pada perusahaan pertambangan batu bara yang terdaftar di BEI tahun 2012-2015? 5. Apakah Reputasi Auditor memiliki pengaruh positif secara signifikan terhadap penerimaan opini terkait going concern pada perusahaan pertambangan batu bara yang terdaftar di BEI tahun 2012-2015? 


\section{METODE PENELITIAN}

\section{Populasi dan Teknik Pemilihan Sampel}

Populasi dalam penelitian ini adalah seluruh perusahaan pertambangan batu bara yang terdaftar pada Bursa Efek Indonesia tahun 2012-2015. Metode pengumpulan data dilakukan dengan menggunakan metode pengambilan sampel purposive. Teknik ini mengambil sampel dari tempat tertentu (dalam hal ini Bursa Efek Indonesia) dan menggunakan kriteria untuk tujuan tertentu yang dianggap potensial dalam penelitian ini. Adapun kriteria-kriteria tersebut adalah: 1. Perusahaan-perusahaan pertambangan batu bara yang terdaftar di Bursa Efek Indonesia selama tahun penelitian 2012 - 2015. 2. Perusahaan yang mengeluarkan laporan keuangan lengkap yang berakhir pada periode 31 Desember dan telah diaudit oleh kantor akuntan publik. 3. Mempunyai data lengkap (harga saham harian, IHSG, nilai kapitalisasi pasar). 4. Tersedianya data tanggal pengumuman laporan keuangan perusahaan.

\section{Variabel Penelitian Dan Teknik Pengolahan Data}

1. Variabel Dependen (Y)

Variabel dependen dalam penelitan ini adalah opini audit going concern.

2. Variabel Independen (X)

Variabel independen dalam penelitian ini terdiri dari lima variabel, meliputi: Pertumbuhan perusahaan, kepemilikan institusional, ukuran perusahaan, prediksi kebangkrutan dan reputasi auditor.

\section{Teknik Pengolahan Data}

Data diuji menggunakan teknik analisis kuantitatif atau teknik analisis statistik. Dalam hal ini menggunakan alat statistik SPSS versi 22.00 yang terkomputerisasi.

Teknik analisis data yang digunakan adalah:

(a) Statistik Deskriptif, analisis ini digunakan untuk menggambarkan karakteristik sampel yang diujikan. Analisis ini menghitung nilai Min, Max, Mean, Standar Deviasi, dan Variansinya.

(b) Analisis Regresi Logit

Analisis regresi logit digunakan di mana variabel dpendennya bersifat kualitatif. Tujuan dari model regresi dengan respon kualitatif pada variabel dependen adalah untuk menentukan probabilitas individu dalam keputusan yang bersifat kualitatif.

- Uji Goodness Of Fit $\left(\mathrm{R}^{2}\right)$, bertujuan untuk mengetahui kebaikan model sebagaimana uji goodness of fit model regresi linear berganda dengan menggunakan ukuran koefisien determinasi. Koefisien determinasi $\left(\mathrm{R}^{2}\right)$ di dalam regresi logistik mengukur proporsi varian di dalam variabel independen yang dijelaskan oleh variabel independen. Namun koefisien determinasi $\left(\mathrm{R}^{2}\right)$ sebagai ukuran kebaikan garis regresi adalah ukuran yang kurang baik (poor measure) di dalam regresi logistik, tidak sebagaimana koefisien di dalam regresi linear. Karena itu, sebagai ukuran kebaikan garis regresi di dalam regresi logistik disebut dengan ukuran yang palsu $\left(\right.$ Pseudo $\mathrm{R}^{2}$ ). Ada dua ukuran Pseudo $\mathrm{R}^{2}$ ini yang bisa digunakan untuk mengukur kebaikan garis regresi di dalam model regresi logistik yaitu:

1. Pseudo $\mathrm{R}^{2}$ Cox and Snell

2. Pseudo $\mathrm{R}^{2}$ Nagelkerke

Ukuran statistika ini sama dengan koefisien determinasi $\mathrm{R}^{2}$ dimana semakin besar nilainya semakin baik garis regresi logistik yang kita miliki. Namun statistika Cox dan Snell $\mathrm{R}^{2}$ ini mengandung kelemahan yaitu nilainya tidak pernah mendekati satu. Dengan 
adanya kelemahan ini maka selanjutnya Nagelkerke membuat modifikasi model Cox dan Snell $\mathrm{R}^{2}$ sehingga bisa menghasilkan nilai antara 0 dan 1 .

- Uji Overal Model Fit, untuk mengetahui apakah semua variabel independen di dalam regresi logistik secara serentak mempengaruhi variabel dependen sebagaimana uji $\mathrm{F}$ di dalam regresi linear. Uji serentak koefisien regresi model logistik dihitung dari perbedaan nilai - 2LL antara model dengan hanya terdiri dari konstanta dan model yang diestimasi yang terdiri dari konstanta dan variabel independen. Uji statistika -2LL ini atau uji LR mengikuti distribusi Chi Square dengan derajat kebebasan n-k. Jika nilai Chi Square $\left(X^{2}\right)$ hitung lebih besar dari nilai kritis atau nilai tabel Chi Square $\left(X^{2}\right)$ maka kita menolak hipotesis nol yang berarti semua variabel penjelas secara bersama-sama mempengaruhi variabel dependen. Sebaliknya jika sebaliknya maka kita menerima hipotesis nol yang berarti semua variabel penjelas secara bersama-sama tidak mempengaruhi variabel dependen.

- Uji Signifikansi Variabel Independen Secara Individual

Uji signifikansi variabel independen ini sama dengan uji signifikansi menggunakan uji t pada model regresi linear berganda sebelumnya. Di dalam model regresi berganda uji signifikansi yang kita lakukan adalah untuk mengetahui apakah koefisien variabel independen secara statistika signifikan berbeda dengan o atau tidak. Jika secara uji statistika berbeda dengan o maka dikatakan bahwa secara statistika variabel independen mempengaruhi variabel dependen.

Uji signifikansi di dalam model logit ini dilakukan sama dengan uji t pada regresi linear berganda yaitu untuk mengetahui apakah koefisien variabel independen di dalam model logit berbeda dengan o atau tidak. Uji signifikansi model logit ini menggunakan uji statistika Wald. Dari uji statistika Wald ini kita bisa mengetahui apakah variabel independen mempengaruhi variabel dependen di dalam model regresi logistik. Sebagaimana uji statistika t dalam model regresi, maka jika probabilitas Chi Squares lebih kecil dari tingkat signifikansi $(\alpha=5 \%)$ maka signifikan dan sebaliknya jika Chi Squares lebih besar dari tingkat signifikansi $(\alpha=5 \%)$ maka tidak signifikan.

Persamaan dalam penelitian ini adalah:

GC_OPINI $=\alpha_{i}+\beta$ GROW $+\beta$ INTS $+\beta$ SIZE $+\beta$ BANKRUPT $+\beta$ KUA $+\varepsilon$

dimana:

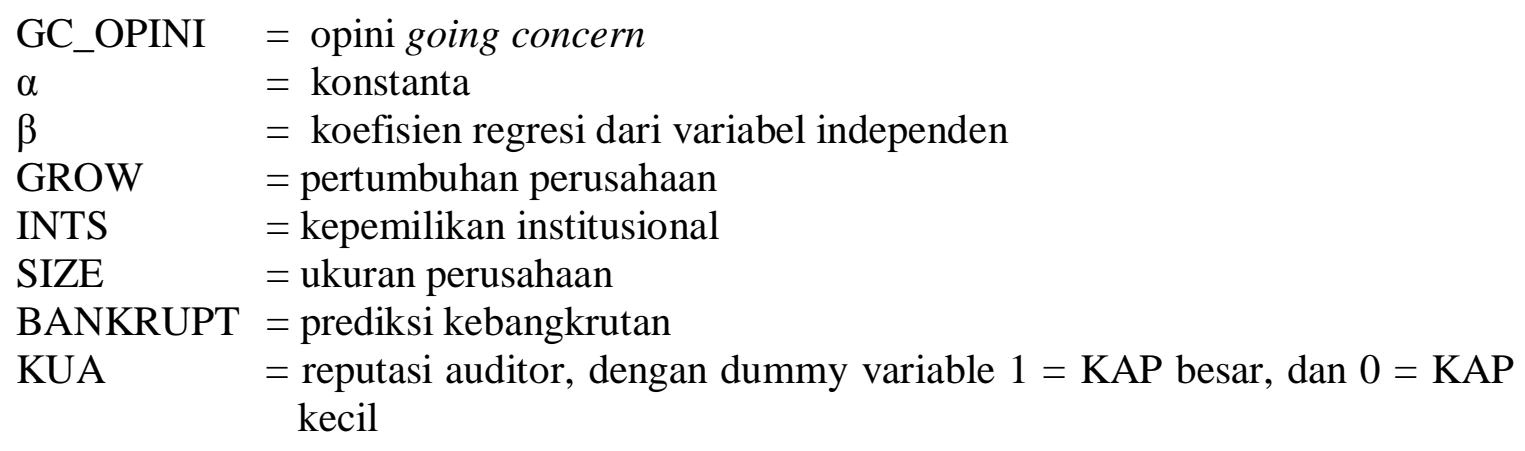




\section{Model Penelitian}

Penelitian ini menggunakan tiga variabel, di mana terdapat lima variabel independen dan satu variabel dependen. Variabel independen dalam penelitian ini adalah pertumbuhan perusahaan, kepemilikan institusional, ukuran perusahaan, prediksi kebangkrutan dan reputasi auditor. Variabel dependen dalam penelitian ini adalah penerimaan opini audit going concern. Model penelitian dalam penelitian ini adalah:

\section{Gambar 1. Model Penelitian}

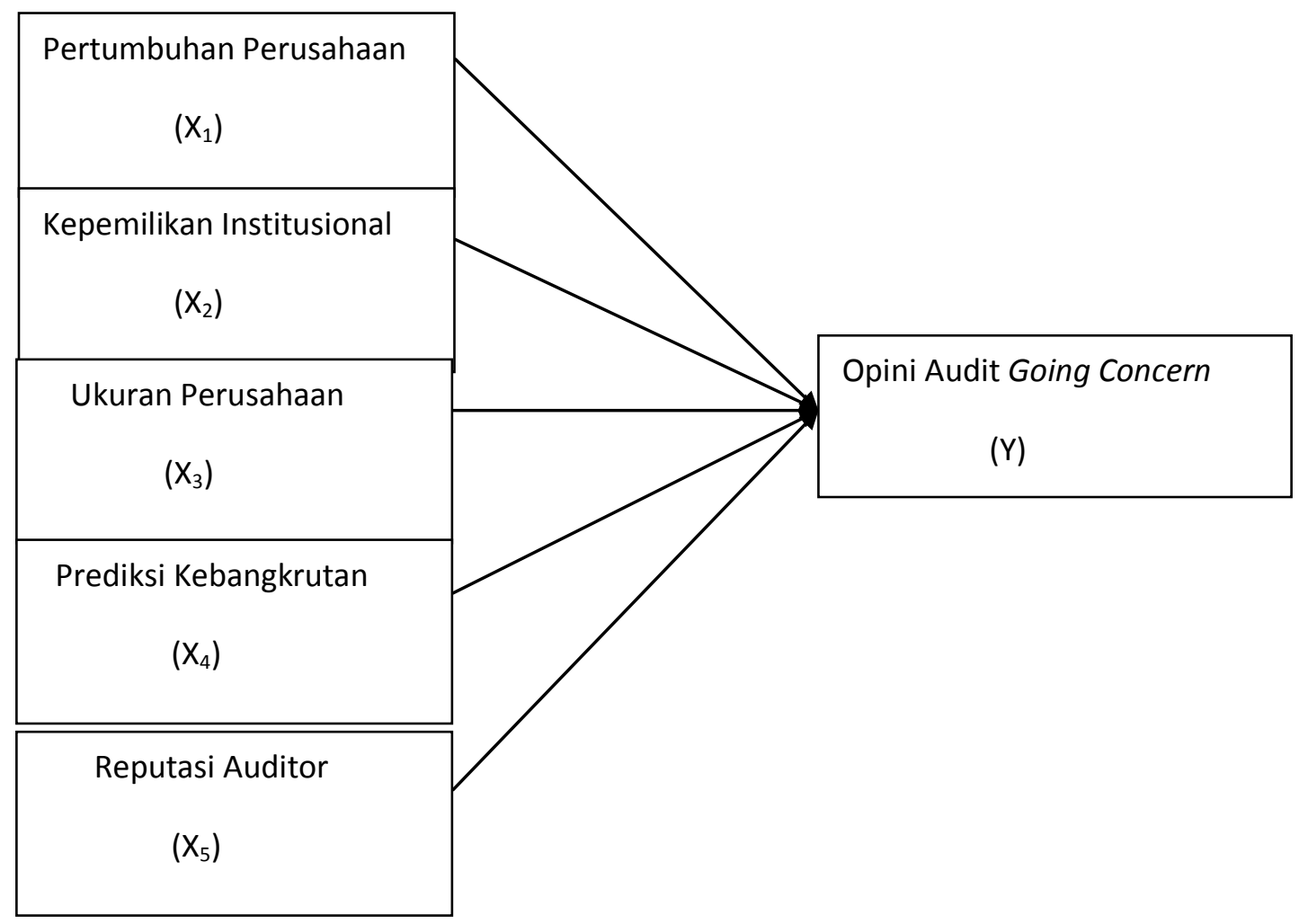

\section{HASIL DAN PEMBAHASAN}

Penelitian ini dilakukan dengan tujuan untuk melihat dan menganalisis pengaruh dari variabel independen yaitu $X_{1}, X_{2}, X_{3}, X_{4}$, dan $X_{5}$ di mana $X_{1}$ merupakan pertumbuhan perusahaan, $X_{2}$ merupakan kepemilikan institusional, $\mathrm{X}_{3}$ merupakan Ukuran Perusahaan, $\mathrm{X}_{4}$ merupakan $\mathrm{Z}$ Score dan $\mathrm{X}_{5}$ merupakan Reputasi Auditor terhadap variabel dependen yaitu Opini Audit terkait Going Concern.

Tabel 1. Kriteria Pengambilan Sampel Penelitian

\begin{tabular}{|l|c|}
\hline \multicolumn{1}{|c|}{ Kriteria } & Jumlah Perusahaan \\
\hline $\begin{array}{l}\text { Perusahaan Pertambangan Batu Bara yang terdaftar di } \\
\text { BEI tahun 2012-2015 }\end{array}$ & 21 \\
\hline $\begin{array}{l}\text { Perusahaan Pertambangan Batu Bara yang tidak lengkap } \\
\text { laporan keuangannya }\end{array}$ & 5 \\
\hline Jumlah Sampel & 16 \\
\hline Jumlah Sampel selama 4 tahun & 64 \\
\hline
\end{tabular}


Tabel 2. Omnibus Tests of Model Coefficients Omnibus Tests of Model Coefficients

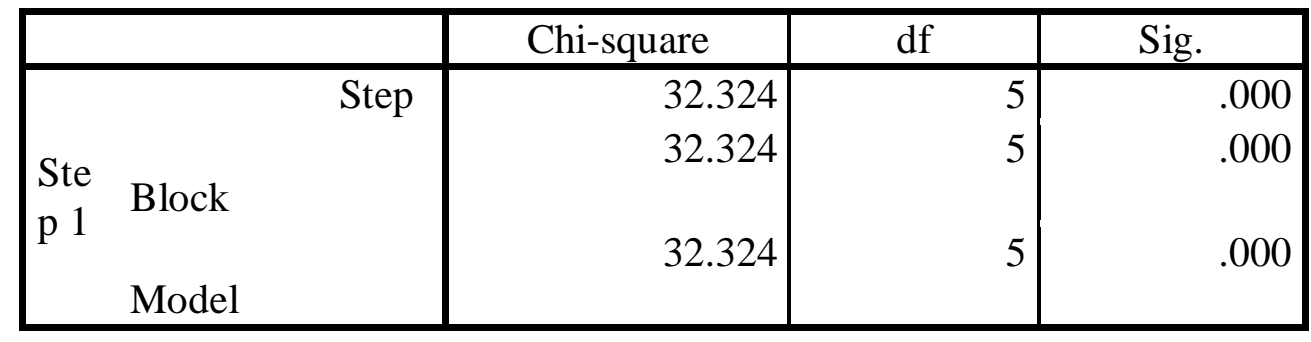

Pada tabel 2 di atas menyajikan informasi uji serentak semua koefisien variabel di dalam regresi kogistik. Nilai Chi Square model adalah sebesar 32,324 dengan df sebesar 5. Nilai Chi Square menunjukkan nilai signifikan pada kolom sign (sign 0,000), sehingga dapat dikatakan bahwa Pertumbuhan Perusahaan, Kepemilikan Institusional, Ukuran Perusahaan, Z Score, Reputasi Auditor akan mempengaruhi keputusan dalam memberikan opini audit terkait going concern.

Tabel 3. Statiktik Deskriptif

Descriptive Statistics

\begin{tabular}{|l|r|r|r|r|r|}
\hline & $\mathrm{N}$ & Minimum & Maximum & Mean & \multicolumn{1}{c|}{$\begin{array}{c}\text { Std. } \\
\text { Deviation }\end{array}$} \\
\hline GROWTH & 64 & .69 & 9.87 & 1.2009 & 1.13117 \\
QINSTITUSI & 64 & .26 & 2.77 & .6402 & .35054 \\
SIZE & 64 & 7.99 & 13.23 & 9.6482 & 1.64892 \\
ZSCORE & 64 & -.49 & 77.14 & 5.3886 & 10.73020 \\
KAP & 64 & .00 & 1.00 & .6094 & .49175 \\
OPINIAUDIT & 64 & .00 & 1.00 & .8125 & .39340 \\
Valid N & 64 & & & & \\
(listwise) & & & & & \\
\hline
\end{tabular}

Berdasarkan data tabel 3 di atas terlihat bahwa variabel Growth pada perusahaan pertambangan batu bara tahun 2012-2015 menunjukkan nilai minimum sebesar 69\%, maksimum sebesar $98,7 \%$, rata-rata sebesar $120,01 \%$ dengan standar deviasai sebesar $113 \%$ yang dapat dikatakan bahwa perusahaan pertambangan batu bara yang terdaftar di BEI tahun 2012-2015 mengalami pertumbuhan aktiva rata-rata sebesar $120 \%$ setiap tahunnya. Nilai Q Institusi yaitu mengukur besarnya jumlah saham yang dimiliki oleh institusi dari jumlah saham perusahaan yang beredar. Berdasarkan data pada tabel di atas, Q Institusi menunjukkan nilai minimum sebesar $26 \%$, nilai maksimum sebesar 277\%, nilai rata-rata sebesar 64,02\% dengan standar deviasi sebesar 35,05\% yang dapat dikatakan juga bahwa rata-rata pemegang saham pada perusahaan pertambangan batu bara yang terdaftar di Bursa Efek Indonesia (BEI) sebesar 64,2\% dimiliki oleh institusi. Untuk nilai size perusahaan yang dihitung dengan menggunakan LOG Aktiva menunjukkan ratarata sebesar $964,82 \%$ yang dapat dikatakan bahwa rata-rata total aktiva perusahaan pertambangan batu bara menunjukkan nilai yang besar. Nilai Z Score menunjukkan nilai minimum sebesar $-0,49$, nilai maksimum sebesar 77,14 , sedangkan nilai rata-rata sebesar 5,38 dengan standar deviasi sebesar 10,73. Hal ini dapat dikatakan bahwa rata-rata nilai Z Score menunjukkan nilai sebesar 5,38 yang menunjukkan rata-rata perusahaan pertambangan batu bara tahun 2012-2015 berada pada keadaan sehat. Nilai KAP pada tabel di atas menunjukkan ratarata sebesar 0,61 yang dapat dikatakan bahwa rata-rata perusahaan pertambangan batu bara tahun 2012-2015 diaudit oleh Kantor Akuntan Publik Big 4 sebesar 61\%. Nilai opini menunjukkan rata-rata sebesar 0,81 yang mendekati angka 1, dimana 1 menunjukkan opini audit non going 
concern, sehingga dapat dikatakan bahwa rata-rata perusahaan pertambangan batu-baru yang terdaftar di Bursa Efek Indonesia (BEI) tahun 2012-2015 memperoleh opini audit non going concern. Hal ini seiring dengan rata-rata Z Score yang menunjukkan nilai 5,38 yang berarti berada pada area sehat sehingga kemungkinan untuk memperoleh opini Going Concern juga semakin besar.

\begin{tabular}{|c|c|c|c|}
\hline \multicolumn{4}{|c|}{$\begin{array}{l}\text { Tabel 4. Goodness Of Fit }\left(\mathrm{R}^{2}\right) \\
\text { Model Summary }\end{array}$} \\
\hline Step & $\begin{array}{l}-2 \text { Log } \\
\text { likelihood }\end{array}$ & $\begin{array}{l}\text { Cox \& Snell R } \\
\text { Square }\end{array}$ & $\begin{array}{l}\text { Nagelkerke R } \\
\text { Square }\end{array}$ \\
\hline 1 & $29.446^{\mathrm{a}}$ & .397 & .641 \\
\hline
\end{tabular}

a. Estimation terminated at iteration number 10 because parameter estimates changed by less than .001 .

Pada tabel 4 di atas menunjukkan nilai Nagelkerke $\mathrm{R}$ Square $\left(\mathrm{R}^{2}\right)$ sebesar $64,1 \%$ yang dapat dikatakan bahwa variabel pertumbuhan perusahaan/growth $\left(\mathrm{X}_{1}\right)$, kepemilikan institusional $\left(\mathrm{X}_{2}\right)$, Ukuran Perusahaan $\left(\mathrm{X}_{3}\right)$, Z Score $\left(\mathrm{X}_{4}\right)$, dan reputasi auditor $\left(\mathrm{X}_{5}\right)$ di dalam model logit mampu menjelaskan penerbitan opini audit terkait Going Concern sebesar 64,1\%.

Tabel 5. Overal Model Fit (F)

Hosmer and Lemeshow Test

\begin{tabular}{|c|c|c|c|}
\hline Step & Chi-square & $\mathrm{df}$ & Sig. \\
\hline 1 & 4.089 & 8 & .849 \\
\hline
\end{tabular}

Dari tabel 5 di atas menunjukkan nilai signifikansi sebesar 0,849 di mana nilai signifikansi > 0,05 , yang artinya tidak signifikan maka probabilitas yang diprediksi sesuai dengan probabilitas yang diobservasi. Berdasarkan hasil analisis data diperoleh nilai signifikan $(0,849>0,05)$ yang menunjukkan bahwa tidak signifikan sehingga $\mathrm{H}_{1}$ ditolak, $\mathrm{H}_{0}$ diterima. Dapat dikatakan bahwa semua variabel independen yaitu pertumbuhan perusahaan $\left(\mathrm{X}_{1}\right)$, kepemilikan institusional $\left(\mathrm{X}_{2}\right)$, ukuran perusahaan $\left(\mathrm{X}_{3}\right)$, $\mathrm{z}$ score $\left(\mathrm{X}_{4}\right)$, reputasi auditor $\left(\mathrm{X}_{5}\right)$ secara bersamaan tidak memiliki pengaruh signifikan terhadap penerbitan opini audit terkait going concern.

Tabel 6. Classification Table

Classification Table $^{a}$

\begin{tabular}{|r|l|r|r|r|}
\hline & Observed & \multicolumn{3}{|c|}{ Predicted } \\
\cline { 3 - 4 } & & \multicolumn{2}{|c|}{ OPINIAUDIT } & \multicolumn{2}{c|}{$\begin{array}{c}\text { Percentage } \\
\text { Correct }\end{array}$} \\
\cline { 3 - 4 } & & .00 & 1.00 & 66.7 \\
Step & OPIN .00 & 3 & 4 & 94.2 \\
1 & DIT 1.00 & & & \\
& Overall Percentage & & & \\
\hline
\end{tabular}

a. The cut value is .500

Pada tabel 6 di atas menunjukkan seberapa baik model mengelompokkan kasus ke dalam dua kelompok yaitu dalam hal ini penerbitan opini audit terkait going concern dengan opini audit non going concern. Keakuratan prediksi secara menyeluruh sebesar 89,1\%, dimana keakuratan 
prediksi penerimaan opini going concern sebesar $66,7 \%$ dan penerimaan opini non going concern sebesar $94,2 \%$.

Tabel 7. Uji Wald

Variables in the Equation

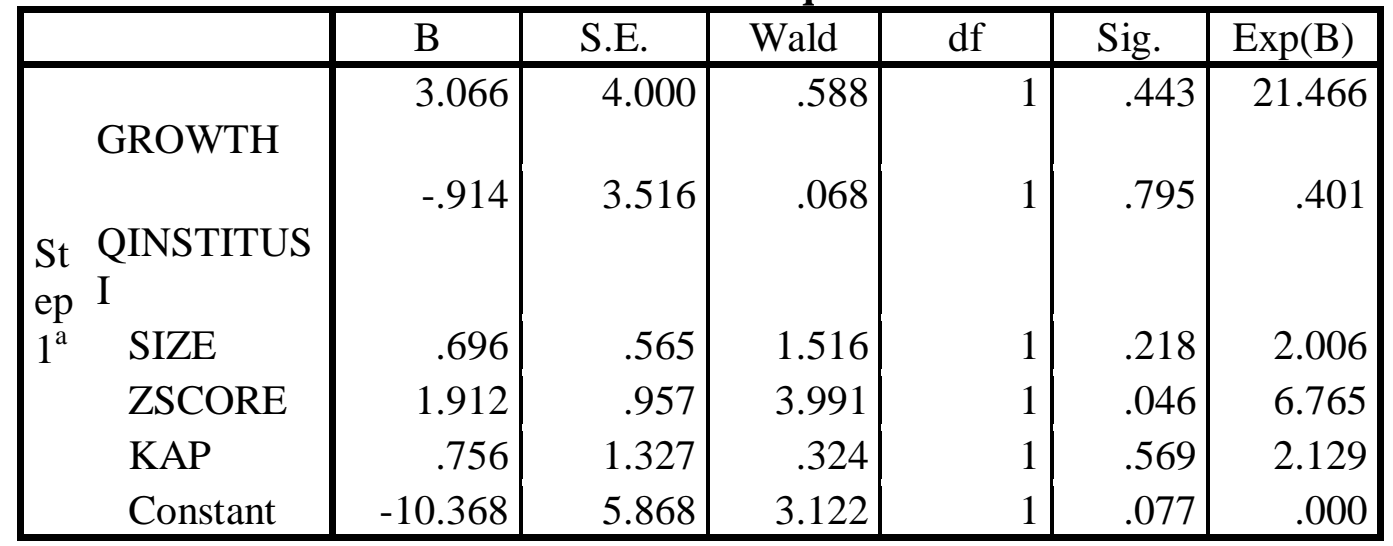

a. Variable(s) entered on step 1: GROWTH, QINSTITUSI, SIZE, ZSCORE, KAP.

Berdasarkan tabel 7 di atas menunjukkan nilai Wald dengan tingkat signifikansi dari masingmasing variabel independen yaitu Growth, Q Institusi, Size, Z Score, KAP memiliki tanda yang positif. Uji signifikansi secara individual menunjukkan bahwa variabel pertumbuhan (growth) dengan nilai sign $(0,443>0,05)$ yaitu $\mathrm{H}_{0}$ diterima, $\mathrm{H}_{1}$ ditolak yang artinya bahwa variabel growth tidak signifikan mempengaruhi penerbitan opini audit terkait going concern. Variabel Q Institusi yaitu besarnya saham kepemilikan institusional terhadap saham perusahaan yang beredar menunjukkan nilai sign $(0,795>0,05)$ yang artinya $\mathrm{H}_{1}$ ditolak di mana kepemilikan institusional tidak memiliki pengaruh signifikan terhadap penerbitan opini terkait going concern. Variabel Size yang mengukur nilai total aktiva perusahaan menunjukkan nilai sign $(0,218>0,05)$ yang artinya $\mathrm{H}_{1}$ ditolak yaitu menunjukkan bahwa variabel Size tidak memiliki pengaruh signifikan terhadap penerbitan opini terkait going concern. Variabel Z Score yang digunakan untuk mengukur indikasi perusahaan mengalami financial distress menunjukkan nilai sign $(0,04$ $<0,05)$ yang artinya $\mathrm{H}_{1}$ diterima di mana variabel $\mathrm{Z}$ Score memiliki pengaruh signfikan terhadap penerbitan opini audit terkait going concern. Variabel KAP yaitu kantor akuntan publik big 4 dan non big 4 menunjukkan nilai sign $(0,56>0,05)$ yang artinya $\mathrm{H}_{1}$ ditolak di mana variabel KAP tidak memiliki pengaruh signifikan terhadap penerbitan opini audit terkait going concern. Bila dilihat dari kelima variabel independen yaitu pertumbuhan, kepemilikan institusional, ukuran perusahaan, z score, reputasi auditor maka hanya variabel z score yang menunjukkan nilai signifikansi yaitu yang memiliki pengaruh signifikan terhadap penerbitan opini terkait going concern.

\section{Hasil Uji Regresi Berganda}

Analisis regresi yang digunakan adalah uji regresi berganda dengan menggunakan analisis regresi logit. Variabel independen dalam penelitian ini adalah pertumbuhan perusahaan/growth $\left(\mathrm{X}_{1}\right)$, kepemilikan institusional $\left(\mathrm{X}_{2}\right)$, ukuran perusahaan/size $\left(\mathrm{X}_{3}\right)$, Z Score $\left(\mathrm{X}_{4}\right)$, reputasi auditor $\left(\mathrm{X}_{5}\right)$ dna variabel dependen adalah opini audit terkait going concern $(\mathrm{Y})$.

Persamaan regresi berganda tersebut dapat ditulis sebagai berikut: 


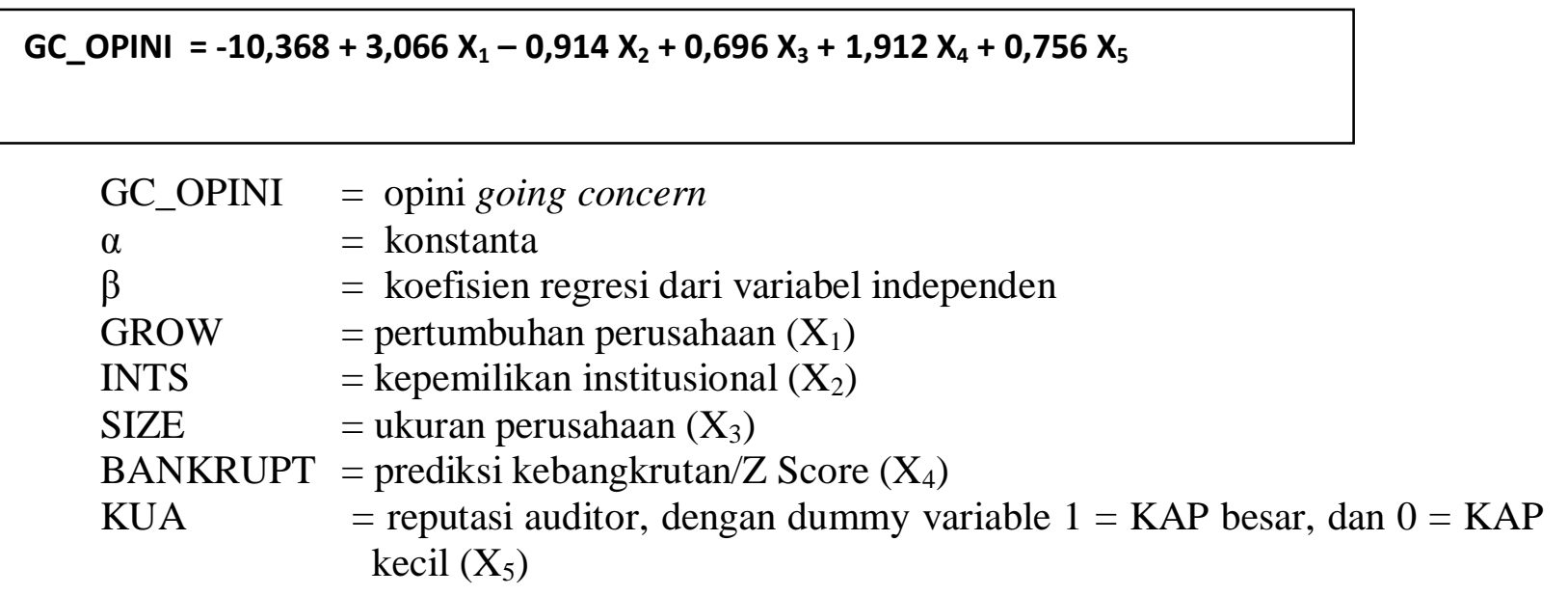

Nilai koefisien regresi logit (B) tidak dapat diinterpretasikan secara langsung. Untuk dapat menginterpretasikan maka akan digunakan nilai antilog dari B atau pangkat eksponensial dari koefisien logit. Nilai dari antilog koefisien B dapat dilihat pada kolom Exp (B) pada tabel 7 di atas.

Berdasarkan hasil uji Wald menunjukkan nilai sign untuk pertumbuhan perusahaan, kepemilikan institusional, ukuran perusahaan dan reputasi auditor yang tidak signifikan, maka dapat dikatakan bahwa nilai odd koefisien Exp (B) tidak memiliki pengaruh terhadap penerbitan opini audit going concern. Hal ini berbeda dengan variabel $\mathrm{Z}$ score yang menunjukkan nilai sign yang signifikan yang artinya bahwa nilai odd koefisien Exp (B) akan memiliki pengaruh kenaikan setiap unit yang dihasilkan oleh Z Score terhadap penerbitan opini audit terkait going concern.

\section{KESIMPULAN DAN SARAN}

\section{Kesimpulan}

Berdasarkan hasil pengujian dan analisis data pada perusahaan pertambangan batu bara yang terdaftar pada Bursa Efek Indonesia (BEI) tahun 2012-2015 serta pembahasan pada bab V dengan menggunakan analisis regresi logit maka dapat disimpulkan sebagai berikut:

1. Bukti empiris menunjukkan bahwa pertumbuhan perusahaan yang dilihat dari peningkatan jumlah aktiva akhir tahun dibandingkan dengan awal tahun perusahaan tidak berpengaruh signifikan terhadap penerimaan opini going concern. Hal ini dapat dikatakan bahwa auditor pada kantor akuntan publik akan melakukan audit dengan menjalankan semua prosedur audit untuk menilai kewajaran suatu laporan keuangan perusahaan untuk mendukung penerbitan suatu opini audit yang berdasarkan keadaan yang sebenarnya. Hasil penelitian ini sejalan dengan Kurniati (2012) yang melakukan penelitian terhadap variabel prediksi kebangkrutan, pertumbuhan dan reputasi KAP terhadap opini audit going concern menyatakan bahwa variabel prediksi kebangkrutan yang berpengaruh signifikan terhadap penerimaan opini audit going concern sedangkan variabel pertumbuhan perusahaan dan reputasi auditor tidak berpengaruh signifikan terhadap penerimaan opini audit going concern. Penelitian yang dilakukan oleh Halimah (2011) menyatakan bahwa debt default berpengaruh terhadap penerimaan opini audit going concern, sedangkan kualitas audit dan pertumbuhan perusahaan tidak berpengaruh terhadap penerimaan opini audit going concern.

2. Bukti empiris menunjukkan bahwa kepemilikan institusional tidak berpengaruh signfikan terhadap penerimaan opini terkait going concern. Hal ini dapat dikatakan bahwa besarnya 
saham yang dimiliki oleh institusi tidak menjadikan perusahaan menjadi lebih baik kinerjanya. Auditor dalam hal ini harus melakukan pemeriksaan menyeluruh terhadap kewajaran suatu laporan keuangan dalam memberikan suatu opini audit dan tidak berdasarkan pada besarnya jumlah saham yang dimiliki oleh institusi. Hal ini sejalan dengan penelitian Indira Januarti (2009) yang menyatakan bahwa financial distress, audit lag, opinion shopping, institutional ownership tidak berpengaruh terhadap opini going concern.

3. Bukti empiris menunjukkan bahwa ukuran perusahaan (size) tidak memiliki pengaruh signifikan terhadap penerimaan opini going concern. Ukuran perusahaan dihitung dengan menggunakan $\log$ terhadap total aktiva perusahaan di akhir tahun. Hal ini dapat dikatakan bahwa auditor pada kantor akuntan publik dalam melakukan audit terhadap kewajaran laporan keuangan perusahaan akan menjalankan semua prosedur audit untuk memperoleh hasil yang baik dan memperoleh keyakinan yang baik dalam hal memberikan opini audit terhadap suatu perusahaan pertambangan batu bara. Hasil penelitian ini tidak sejalan dengan Indira Januarti (2009) yang menyatakan bahwa bahwa debt default, size, auditor client tenure, prior opinion, auditor quality berpengaruh signifikan terhadap opini going concern. Financial distress, audit lag, opinion shopping, institutional ownership tidak berpengaruh terhadap opini going concern.

4. Bukti empiris menunjukkan bahwa prediksi kebangkrutan memiliki pengaruh signifikan terhadap penerimaan opini terkait going concern. Prediksi kebangkrutan atau financial distress yang dihitung dengan menggunakan analisis rasio $Z$ Score terhadap modal kerja, profitabilitas, penjualan, dan laba ditahan menunjukkan hasil yang signifikan dalam penerimaan opini audit going concern. Hal ini dapat dikatakan bahwa auditor dalam melakukan audit terhadap kewajaran suatu laporan keuangan perusahaan pertambangan batu bara akan melakukan penilaian dan analisis terhadap rasio keuangan perusahaan untuk mengetahui kinerja perusahaan. Hasil perhitungan rasio keuangan ini akan menunjukkan kondisi sebenarnya perusahaan yang akan berpengaruh terhadap opini audit yang akan diberikan oleh kantor akuntan publik. Hasil penelitian ini sejalan dengan Yulius Kurnia Susanto (2009) yang menyatakan bahwa kondisi keuangan perusahaan (Altman Model), return on assets, debt to total assets dan prior opinion berpengaruh secara signifikan terhadap kemungkinan penerimaan opini going concern, sedangkan current ratio, quick ratio, cash flow from operation, debt to equity, long term debt to total assets, audit quality, debt default and opinion shopping tidak berpengaruh signifikan terhadap penerimaan opini going concern. Selanjutnya hasil penelitian dari Wiwik Kurniati (2012) juga menunjukkan hasil yang sama yaitu bahwa variabel prediksi kebangkrutan yang berpengaruh signifikan terhadap penerimaan opini audit going concern, sedangkan pertumbuhan perusahaan dan reputasi Kantor Akuntan Publik tidak berpengaruh terhadap opini audit going concern. Namun hasil penelitian Indira Januarti (2009) terhadap perusahaan manufaktur menunjukkan hasil yang berbeda yang menyatakan bahwa Financial distress, audit lag, opinion shopping, institutional ownership tidak berpengaruh terhadap opini going concern.

5. Bukti empiris menunjukkan bahwa reputasi auditor tidak berpengaruh signifikan terhadap penerimaan opini going concern. Reputasi auditor yang dibedakan menjadi KAP big four dan KAP non bigfour, hal ini menunjukkan bahwa semua KAP akan selalu berhati-hati dalam melakukan pemeriksaan terhadap kewajaran laporan keuangan perusahaan pertambangan batu bara. Auditor akan menjalankan semua prosedur audit untuk memperoleh keyakinan bahwa laporan keuangan bebas dari salah saji yang material. Prosedur audit meliputi analisis, pengumpulan bukti, prosedur analitis yang dijalankan oleh semua KAP yang akan dirangkum dalam suatu kertas kerja pemeriksaan untuk mendukung suatu opini audit yang akan diberikan. KAP non big four dengan menggunakan sumber daya yang ada akan tetap melakukan semua prosedur audit dengan baik. Hal ini sejalan dengan hasil 
penelitian yang dilakukan oleh Ayu Wilujeng Rahayu dan Caecilia Widi Pratiwi (2011) yang menunjukkan hasil bahwa pertumbuhan perusahaan, rasio leverage, dan reputasi auditor tidak berpengaruh terhadap penerimaan opini audit going concern.

\section{Saran}

\section{Bagi pihak Perusahaan Pertambangan Batu Bara}

Berdasarkan hasil pengujian hipotesis terhadap kelima variabel independen yang menunjukkan bahwa prediksi kebangkrutan dengan menggunakan model Altman Z Score memiliki pengaruh yang signifikan terhadap penerbitan opini audit going concern terhadap perusahaan pertambangan batu bara tahun 2012-2015. Dengan menggunakan Model Altman Z-Score dengan menghitung ke lima rasio keuangan dalam memprediksi kebangkrutan sebaiknya mendapatkan perhatian yang serius dari pihak manajemen perusahaan. Pihak manajemen perusahaan sebaiknya lebih berhati-hati dalam mengelola aktiva perusahaan dan jangan sampai arus modal kerja yang dihasilkan menjadi negatif. Dengan modal kerja yang negatif akan mengganggu bisnis operasional perusahaan, di mana penjualan dan laba perusahaan akan mengalami penurunan. Hutang yang terus meningkat juga akan mengakibatkan kinerja perusahaan terganggu. Piutang yang terlalu besar juga akan mengganggu kelancaran arus kas perusahaan, sehingga dalam hal ini perusahaan juga harus selektif dalam memilih customer dalam hal penjualannya, dan jangan sampai meningkatnya penjualan diiringi dengan meningkatnya bad debt pada piutang perusahaan. Dengan meningkatnya kinerja keuangan perusahaan pertambangan batu bara maka akan meningkatkan pendapatan dan laba perusahaan dan selanjutnya juga akan menarik minat investor untuk menanamkan modalnya pada saham perusahaan pertambangan batu bara.

\section{Bagi Penelitian Selanjutnya}

Penelitian selanjutnya diharapkan dapat memasukkan variabel independen lainnya seperti pertumbuhan ekonomi, tingkat pengangguran, tingkat inflasi, harga komoditas, dan lain-lain sehingga dapat lebih menggambarkan secara umum keadaan perusahaan pertambangan batu bara. Penelitian juga sebaiknya dapat lebih diperluas terhadap jenis perusahaan lainnya seperti perusahaan manufaktur, perbankan, dan perdagangan yang terdaftar di Bursa Efek Indonesia (BEI).

\section{Ucapan Terima Kasih (Acknowledgement)}

DPPM Untar, Fakultas Ekonomi Untar, Bursa Efek Indonesia

\section{REFERENSI}

Alichia, Yashinta, 2013. Pengaruh Ukuran Perusahaan, Pertumbuhan Perusahaan, Dan Opini Audit Tahun Sebelumnya Terhadap Opini Audit Going Concern.

Ejournal.unp.ac.id/students/index.php/akt/article/2013.

Altman, E dan McGough., 1974 Evaluation of A Company as A Going Concern. Journal of Accountancy, December. 50-57.

Ardiyos, 2013. Kamus Akuntansi Publik. Jakarta: Citra Harta Prima.

Atmini, S. dan Wuryan, A. (2005). Manfaat Laba dan Arus Kas untuk Memprediksi Kondisi Financial Distress pada Perusahaan Textile Mill Products dan Appareal and Other Textile Products Yang Terdaftar di Bursa Efek Jakarta. SNA VIII: Hal 460-474. 
Bapepam, 2002, Pedoman Penyajian Dan Pengungkapan Laporan Keuangan Emiten Atau Perusahaan Publik, Lampiran 1 Surat Edaran Ketua Bapepam No: SE-02/PM/2002, http://www.bapepam.go.id

Bapepam, 2012, Pedoman Penyajian Dan Pengungkapan Laporan Keuangan Emiten Atau Perusahaan Publik, Salinan Keputusan Bapepam No: KEP-347/BL/2012, http://www.bapepam.go.id

Bapepam, 2003, Kewajiban Penyampaian Laporan Keuangan Berkala, Lampiran Keputusan Ketua Bapepam No. KEP-36/PM/2003, http://www.bapepam.go.id

Carcello, Joseph V.,Hermanson, Roger H. McGrath, Neal T. 1992. "Audit Quality Attributes: The Perception of Audit Partners, Prepares \& Financial Statement Users". Auditing: A Journal of Practice and Theory. 1-15.

Chen, K. C. W.,and B. K. Church, 1996. "Going Concern Opinions and the Market's Reaction to Bankruptcy Filings". The Accounting Review: 117 - 128.

Chen, K.C.W., and B.K. Church, 1992. "Default on Debt Obligation and the Issuance of Going Concern Report". Auditing: A Journal of Practice \& Theory, Fall. 30-49.

DeAngelo, L, 1981. Auditor Independence, "low balling" and Disclosure Regulation. Journal of Accounting and Economics. (August). 113-127.

F. Brigham, Eugene, Joel F. Houston. 2001. Manajemen Keuangan. Edisi Kedelapan. Buku II. Jakarta: Erlangga.

Gabriella. 2011. Analisis Prediksi Kebangkrutan Pada Perusahaan Manufaktur Di Bursa Efek Indonesia. Tugas Akhir Jurusan Akuntansi Politeknik Makassar.

Gerald I. White, Ashwin Paul C. Soudhi, and Dov. Fried, The Analysis and Use Of Financial Statements, John Wisley \& Sons, Inc.,Third Edition, 2003.

Halimah, 2011. Pengaruh Debt Default, Kualitas Audit, dan Pertumbuhan Perusahaan Terhadap Penerimaan Opini Audit Going Concern (Studi Empiris Pada Perusahaan Manufaktur Yang Terdaftar Di Bursa Efek Indonesia Tahun 2010-2012). Jurnal Akuntansi, Volume 11, No. 2, November 2011, Hal: 513-518.

Harjito, Agus. 2012. Dasar-Dasar Teori Keuangan. Yogyakarta: Ekonisia.

Hartono, 2005. Analisis dan Desain Sistem Informasi. Jakarta: Ghalia Indonesia.

Ikatan Akuntan Indonesia, 2007, Standar Akuntansi Keuangan, Jakarta, Salemba Empat.

Ikatan Akuntan Publik Indonesia, 2011. Standar Profesional Akuntan Publik per 31 Maret 2011. Jakarta: Salemba Empat.

Januarti, Indira, 2009. Analisis Pengaruh Faktor Perusahaan, Kualitas Auditor, Kepemilikan Perusahaan Terhadap Penerimaan Opini Audit Going Concern (Perusahaan Manufaktur Yang Teerdaftar Di Bursa Efek Indonesia). Jurnal Bisnis dan Akuntansi, Volume 9, No. 1, Tahun 2009, Hal: 84-108.

Kurniati, Wiwik, 2012. Prediksi Kebangkrutan, Pertumbuhan Dan Reputasi KAP Terhadap Opini Audit Going Concern. Accounting Analysis Journal, Volume 1, No. 1, Tahun 2012.

Mutchler, J.,1985. "A Multivariate Analysis of the Auditor's Going Concern Opinion Decision". Journal of Accounting Research. Autumn. 668-680.

Nariman, Augustpaosa. 2013. Evaluasi Pengaruh Financial Distress Dan Rasio Keuangan Terhadap Opini Dan Pengungkapan (Disclosure) Yang Memadai Dalam Laporan Audit Pada Perusahaan-Perusahaan Manufaktur Yang Terdaftar Di BEI Periode 2005-2007. Jurnal Akuntansi, Volume XVII/01/Januari/2013: 62-74.

Nugroho, Agung, 2005. Strategi Jitu Memilih Metode Statistik Penelitian dengan SPSS. Yogyakarta: Penerbit Andi.

Prihadi, Toto. Deteksi Cepat Kondisi Keuangan, 7 analisis rasio keuangan, Cetakan I-Jakarta; PPM, 2008. 
Prihadi, Toto. Investigasi Laporan Keuangan \& Analisis Rasio Keuangan, Cetakan I-Jakarta; PPM, 2009.

Rahayu dan Pratiwi, 2011. Pengaruh Opini Audit Tahun Sebelumnya, Pertumbuhan Perusahaan, Leverage dan Reputasi Auditor Terhadap Penerimaan Opini Audit Going Concern. Jurnal Ilmiah Akuntansi, Volume 11 No. 2, Tahun 2011.

Ramadhany, Alexander. 2004. Analisis Faktor-Faktor Yang Mempengaruhi Penerimaan Opini Audit Going Concern Pada Perusahaan Manufaktur Yang Mengalami Financial Distress Di Bursa Efek Jakarta. Jurnal Maksi, Volume 4, Hlm. 146-160.

S. Munawir, 2002. Analisis Informasi Keuangan. Yogyakarta: Liberty Yogyakarta Sari, dan Zuhrotun, (2006). "Keinformatifan Laba Di Pasar Obligasi dan Saham: Uji Liquidation Option Hypothesis", Simposium Nasional Akuntansi 9, Padang.

Setyarno, Januarti dan Faisal, 2006. Pengaruh Kualitas Audit, Kondisi Keuangan Perusahaan, Opini Audit Tahun Sebelumnya, Pertumbuhan Perusahaan Terhadap Opini Audit Going Concern. Simposium Nasional Akuntansi 9, Padang 23-26 Agustus 2006.

Sugiyono, 2012. Memahami Penelitian Kualitatif. Bandung: ALFABETA.

Supardi, Sri Mastuti. 2003. Validitas Penggunaan Z-Score Altman Untuk Menilai Kebangkrutan Pada Perusahaan Perbankan Yang Go Public di Bursa Efek Jakarta. KOMPAK No. 7. p.68-93.

Suroso, 2006. Investasi Pada Saham Perusahaan Yang Menghadapi Financial Distress, Usahawan. No. 2. Tahun XXXV.

Surya, Budhi Arta dan Teguh Gunawan Nasher, 2011. Analisis Pengaruh Tingkat Suku Bunga SBI, Exchange Rate, Ukuran Perusahaan, Debt to Equity Ratio, dan Bond terhadap Yield Obligasi Korporasi di Indonesia. Bandung: Jurnal Manajemen Teknologi.

Surya, Dennys dan Deasy A. Rahayuningsih, 2012. Faktor-Faktor yang Mempengaruhi Kebijakan Hutang Perusahaan Non Keuangan yang Terdaftar Dalam Bursa Efek Indonesia. Jurnal Bisnis dan Akuntansi. Vol. 14, No. 3.

Susanti, 2013. Analisis Variabel-Variabel Yang Mempengaruhi Kebijakan Hutang Perusahaan. Jurnal Ilmu Manajemen, Vol. 1, No. 3.

Susanto, Yulius, 2009. Faktor-Faktor Yang Mempengaruhi Penerimaan Opini Audit Going Concern Pada Perusahaan Publik Sektor Manufaktur. Jurnal Bisnis Dan Akuntansi, Volume 11, No. 3, Desember 2009, Hal: 155-173.

Suwardjono, (2005). Teori Akuntansi: Perekayasaan Pelaporan Keuangan, Edisi Ketiga. Yogyakarta, BPFE UGM.

Teoh, S.H., dan T.J. Wong. 1993. "Perceived Auditor Quality and The Earnings Response Coefficient". The Accounting Review. Pp 346-366.

Widarjono, Agus. Analisis Statistika Multivariat Terapan, Edisi Pertama, Cetakan Pertama: Februari 2010. Yogyakarta: Sekolah Tinggi Ilmu Manajemen YKPN, Yogyakarta.

Wuryatiningsih. 2002. Bank dan Lembaga Keuangan lainnya, Jakarta :Salemba Empat. Zmijeski, M, 1984. Methodological Issues Related to the Estimation of Financial Distress Prediction Models. Journal of Accounting Research. Supplement. 59-82. 